\title{
Compensation Committee Quality and Effective Executive Remuneration
}

\author{
Simona Catuogno ${ }^{1}$, Claudia Arena ${ }^{1} \&$ Riccardo Viganò ${ }^{1}$ \\ ${ }^{1}$ Department of Economics, Management, Institutions, University of Naples Federico II, Naples, Italy \\ Correspondence: Simona Catuogno, Department of Economics, Management, Institutions, University of Naples \\ Federico II, Via Cinthia 26, 80126, Naples, Italy. Tel: 39-081-675-061. E-mail: simona.catuogno@unina.it
}

Received: March 10, 2016

Accepted: April 11, 2016

Online Published: May 22, 2016

doi:10.5539/ijbm.v11n6p118

URL: http://dx.doi.org/10.5539/ijbm.v11n6p118

\begin{abstract}
Grounding in the agency theory, this paper questions whether high quality compensation committee influences the design of executive remuneration towards the alignment of the contrasting interests between managers and shareholders. Relying on a comprehensive approach that captures the compensation committee quality based on different attributes (i.e. independence, interlocking directorates, directors appointed by minorities) we conduct a two-step empirical analysis. First, we illustrate the evolution over time of the stock option plan characteristics and construct an illustrative diagram that shows the linkages between the attributes of the compensation committee quality and the elements of the option plans. Second, we run a probit regression analysis to deeply investigate the picture emerging from the diagram. Our results document that the quality of compensation committee significantly affects the assignment of incentive stock option plans. The paper evidence advances the knowledge in the literature on compensation committee and executive remuneration, by highlighting that structural characteristics of the committee other than independence of its members play a pivotal role in writing effective remuneration contracts for the executives. Our findings are also useful for investors and policymakers.
\end{abstract}

Keywords: compensation committee, executive remuneration, stock option

\section{Introduction}

In recent years, compensation committees have attracted the attention of scholars, practitioners and regulators due to their pivotal role in defining, administering, overseeing executive compensation and setting the parameters for effective equity remunerations. The quality of compensation committees directly affects executive compensation through the definition of remuneration packages whose aim is to align manager and shareholder interests. Indeed, scholars highlight that high quality compensation committee leads to better designed executive remuneration contracts that motivate managers to take value-maximizing decisions, resulting in higher firm performance (Newman \& Mozes, 1999; Anderson \& Bizjak, 2003; Vafeas, 2003).

Nevertheless, literature has largely focused on the whole board of director structure, neglecting the investigation of its sub-committees (Catuogno, Saggese, Sarto, \& Viganò, 2015). Among the studies exploring the role of board committees, most has focused on the audit rather than the compensation committees (Klein, 2003).

To fill this gap, in this study we investigate whether the quality of compensation committee influences the effectiveness of executive remuneration in aligning the contrasting interests of managers and shareholders by focusing on stock option plans (hereafter SOPs).

Grounding in the agency theory we hypothesize that a high quality compensation committee is capable of implementing better designed executive SOPs reducing the managerial ability to extract rents and leading to stronger incentives for long-term performance.

Answering the call of recent studies (Sun, Cahan, \& Emanuel, 2009; Sun \& Cahan, 2009), we measure compensation committee quality using three metrics: (i) the independence of its constituents; (ii) the interlocking directorates; and (iii) the presence of directors appointed by minority shareholders. Our approach is broader and more comprehensive than other studies that have investigated the compensation committee quality by relying on a single metric, i.e the independence of its members. We capture the effectiveness of SOPs in aligning the interests of managers and shareholders in terms of vesting period equal or longer than 3 years, presence of a lock up period and indexed strike price (Liljeblom, Pasternack, \& Rosenberg, 2011; Qin, 2012; Abernethy, Kuang, \& 
Qin, 2015).

Using a sample of Italian listed companies issuing SOPs, all of which with compensation committees, we find evidence that the quality of this sub-committee is positively related with the settlement of an indexed strike price. This evidence supports the view that higher compensation committee quality results in executive compensation contracts that incentives the alignment aim of SOPs, and as a consequence, reduces the rent extraction of private benefits at the expense of outside shareholders.

We contribute to the existing literature in several ways. We broaden the current knowledge in governance studies by exploring the composition of a relevant, although under investigated, board committee. More specifically, we assess whether and how the composition of compensation committee influences the effectiveness of SOPs in aligning managerial interests to those of outside shareholders. Furthermore, we introduce a measure of compensation committee quality, which is broader than the deeply investigated independence of its members (Daily, Johnson, Ellstrand, \& Dalton, 1998; Conyon \& Peck, 1998; Newman \& Mozes, 1999; Vafeas, 2003; Conyon \& He, 2004; Conyon, 2014). Finally, we identify the elements of the SOPs that define effective executive remuneration contracts, thus providing also useful contributions to practitioners and regulators.

The remainder of the paper is organized as follows: Section 2 reviews the related studies and develops hypotheses. Section 3 explains the method. Section 4 explains the results and Section 5 concludes.

\section{Literature Review and Hypotheses}

\subsection{Compensation Committee Quality and Executive Remuneration}

Compensation committee plays a crucial role for the effectiveness of executive remuneration (Conyon \& Peck, 1998; Gong, 2011). Indeed, in absence of this committee, there would be opportunities for senior executives to award themselves remunerations not congruent with shareholder interests (Williamson, 1985). Notwithstanding the positive effect played by the compensation committee itself, literature suggests that also its quality counts in designing and implementing effective remuneration arrangements that will lead to stronger incentives for subsequent performance (Barkema \& Gomez-Mejia, 1998). For instance, empirical evidence shows that in firms with high compensation committee quality, earnings performance is positively associated with executive compensation (Sun et al., 2009; Sun \& Cahan, 2009).

In order to appreciate the quality of the compensation committee, literature refers to its structural characteristics. The most investigated is connected to its independence (Zona, 2016). Directors having no personal and/or contractual relationship with the firm are expected to act in the interests of outside shareholders when defining an effective executive remuneration. In these respect, scholars highlight that independent non-executive directors hold the responsibility to enhance shareholder protection in order to maintain their reputations (Fama \& Jensen, 1983a) For instance, Melis, Carta, and Gaia (2012) show that boards with a higher proportion of independent directors are more likely to design executive remuneration aimed at alleviating agency conflicts between managers and shareholders. Similarly, Li, Moshirian, Nguyen, and Tan (2007) suggest a positive relation between board independence and CEO compensation in Chinese firms. Moreover, Chhaochharia and Yaniv Grinstein (2009) find that, when the majority of board members are independent, firms experience a significant decreasing of CEO compensation.

Beside the independence, another characteristic that is relevant for the design of effective remuneration packages is the existence of directors with multiple appointments, referred to as interlocking directorate. Within the agency framework, Fama (1980) and Fama and Jenses (1983b) claim that interlocked directors signals experience and reputation that contribute to the pursuit of value creation. In this sense, the simultaneous presence of the same director in the board of different organization may constitute a useful channel for the diffusion of good governance practices among different firms, also in terms of the design of effective remunerations. Similarly, other studies suggest that interlocked directors may increase the board social and relational capital (Pfeffer \& Salancick, 1978), thus reinforcing the board strategic and networking role (Pfeffer, 1991; Carpenter \& Westphal, 2001; Hillman, Keim, \& Luce, 2001). Despite the beneficial role of interlocking directorate, empirical studies on this topic also report opposite results, suggesting that it may decrease board independence (Shivdasani, 1993; Cotter et al., 1997) and result in a weaker corporate performance (Fich \& Shivdasani, 2006).

Scholars suggest that also the presence of directors appointed by minority shareholders matters for the alignment aim of executive remuneration. Indeed, in closely held firms, large blockholders may act at the expense of minority shareholders and expropriate their wealth (Johnson, LaPorta, Lopez-De-Silanes, \& Shleifer, 2000). As controlling owners are usually directors and also top managers of their companies (Melis, 2000), they have the power to influence the board decision making in order to receive pay in excess of the optimal amount for 
shareholders (Bebchuk, Fried, \& Walker, 2002; Bebchuk \& Fried, 2006). With the aim of preventing this expropriation, minority shareholders hold the right to appoint at least one compensation committee director to their own slate. In line with this prediction, empirical studies reveal that when remuneration committees are composed of at least an independent director appointed by minority shareholders, executive remunerations are more effective in aligning the objectives of managers and shareholders (Melis et al., 2012).

\subsection{The Design of Effective SOPS}

Among the executive compensation practices, SOPs are one of the most controversial governance remuneration tools (Core, Guay, \& Larker, 2003; Jensen \& Zajac, 2004; Melis et al., 2012). According to the agency theory, compensation committee has the chance to reward executives with equity options, as the variable amount of the total remuneration, with the aim to align their interests to those of outside shareholders (Jensen \& Meckling, 1976; Fama \& Jensen, 1983a; Jensen \& Murphy, 1990). In this sense, literature suggests that effective SOPs allows to attract, retain, and motivate CEOs, executives, and managers both in widely-held firms (Yermack, 1995; Bebchuk et al., 2002; Core et al., 2003; Gong, 2011) and in concentrated ownership structures (Claessens, Djankov \& Lang, 2000; Barca \& Becht, 2001; Faccio \& Lang, 2002; Melis et al., 2012). However, within the same agency framework, recent governance studies illustrate that when firms are weakly governed ineffective, SOPs are granted to powerful managers, raising the risk of wealth expropriation to the detriment of outside shareholders (Bebchuk \& Fried, 2006; Barontini \& Bozzi, 2009; Liu, Liu, \& Yin, 2014; Arena, Catuogno, Cirillo, \& Pennacchio, 2016).

There are several components of the SOPs design that predict whether these instruments can be effective in aligning the interests of owners and managers (Bebchuk et al., 2002; Zattoni \& Minichilli, 2009). The most relevant characteristics comprise the length of vesting, the lock-up period, the presence of indexed strike price, the strike price at/out the money and the practice of re-pricing (Johnson \& Tian, 2000; Bebchuk et al., 2002; Zattoni, 2007).

The length of the vesting period is the first pivotal characteristic of effective plans' design since a long-term perspective avoids managerial myopia and motivates executive directors to undertake value-maximizing decisions (Fudenberg, Holmstrom, \& Milgrom, 1990; Zattoni, 2007; Peng \& Roell, 2008). In order to encourage SOPs beneficiaries to pursue medium and long term company goals, and to discourage their short-term opportunistic behaviors, some authors suggest that vesting period should be equal or longer than 3 years (Zattoni, 2007; Viscogliosi \& Zattoni, 2008; Melis et al., 2012). Conversely, a shorter vesting period may be symptomatic of non-effective SOPs, since they induce executive directors to take decisions that reduce medium-long term value for shareholders (Palepu \& Healy, 2003).

Similar arguments support the prescription of a lock up period, as another important component of effective SOPs. The presence of a lock-up period encourages the retention of the SOPs beneficiaries, increases loyalty and induces them to act as owners of the firm (Bebchuk et al., 2002).

A third characteristics of the SOPs is the presence of an indexed strike price that allows rewarding executives for the stock price increases that are related to the managerial performance (Kuang \& Quin, 2009). In this perspective, the theory predicts that effective executive compensation should be tied to the firm's outcomes that capture the managerial efforts (Catuogno et al., 2015). As accounting results typically fail to reflect the current value of growth opportunities, the firm stock price is often used as a tool for the evaluation of executive performance (Bebchuk et al., 2002). Accordingly, SOPs should be designed in order to reward managers that contribute to the share price's increase (Johnson \& Tian, 2000; Bertrand \& Mullainathan, 2001). Therefore, SOPs are effective when options become exercisable only if the company stock price outperforms a certain industry, market or accounting benchmark (Hall \& Liebman, 2000).

On the basis of these arguments we expect that the quality of compensation committee, as defined by the presence of independent directors, experienced interlocked directors, as well as directors appointed by minority shareholders, leads to the design of effective SOPs that align managers and shareholders' interests. Thus we formulate the following hypotheses:

HP1: High quality compensation committee is positively related to a vesting period equal or longer than 3 years.

HP2: High quality compensation committee is positively related to the presence of a lock-up period.

HP3: High quality compensation committee is positively related to an indexed strike price. 


\section{Research Method}

\subsection{Sample}

In order to understand whether the compensation committee quality is related to the SOPs effectiveness we explore a sample of 72 Italian listed companies during the period 2008-2010. Our initial sample comprises all the companies listed in Milan Stock Exchange in 2008. We consider all the companies having a compensation committee and an active SOP during our observation period. We delete all the observations for which we were unable to collect the necessary data. The final sample comprises 181 firm SOPs. This setting is particularly suitable for our research as it is representative of a typical corporate governance environment, i.e. that of the closely held firms, very widespread worldwide (LaPorta et al., 1999). In such a context, the overlapping between managers and controlling shareholders increases the risk of expropriation of the corporate wealth at the expense of outside shareholders. For this reason, it is crucial to investigate the corporate governance mechanisms that limit minorities' expropriation, fostering the convergence of interests between insider and outsider investors.

\subsection{Variables}

\subsubsection{Dependent Variables}

We capture the SOPs effectiveness according to the previous literature (Bebchuk, 2002; Bebchuk \& Fried, 2006; Viscogliosi \& Zattoni, 2008). Specifically, we code the vesting period as a dummy variable equals to 1 if the SOP vests in a period equal or longer than 3 years; 0 otherwise (SO_VEP). We measure the presence of the lock up period as a binary outcome equals to 1 if the SOP has a lock up provision, 0 otherwise (SO_LOCKUP). Finally, we code the indexed SOP as a dummy variable equals to 1 if the SOP has a strike price related to an accounting, market or industry performance, 0 otherwise (SO_INDEX).

\subsubsection{Independent and Control Variables}

We capture the compensation committee quality with reference to the following variables. In particular, we measure the committee independence as the percentage of compensation committee directors that are declared as independent in accordance with the Italian Corporate Governance Code, i.e. the "Codice di Autodiscipina" (IND_CC). We code director interlocks as the percentage of compensation committee members that sit simultaneously on the committees of other listed companies, including subsidiaries of the same corporate group (INTERLOCK_CC). We code minority directors as the percentage of directors who are appointed by the minority shareholders (MIN_CC). In line with prior studies, we also control for some characteristics that could influence the effective design of SOPs (Melis et al., 2012). Specifically, we consider the leverage (LEV), the size (SIZE) of company, the age of the firm on the Stock Market (IPO) together with the industry (SEC) to which it belongs. LEV is measured as the ratio between the debt over total asset. SIZE is measured as the natural logarithm of employees. IPO is measured as the age of the firms starting from its initial public offerings. SEC is defined according to the standard two-digit SIC code classification.

\section{Results}

\subsection{Descriptive Analysis}

Figure 1 reports the distribution of the SOPs according to their characteristics. 


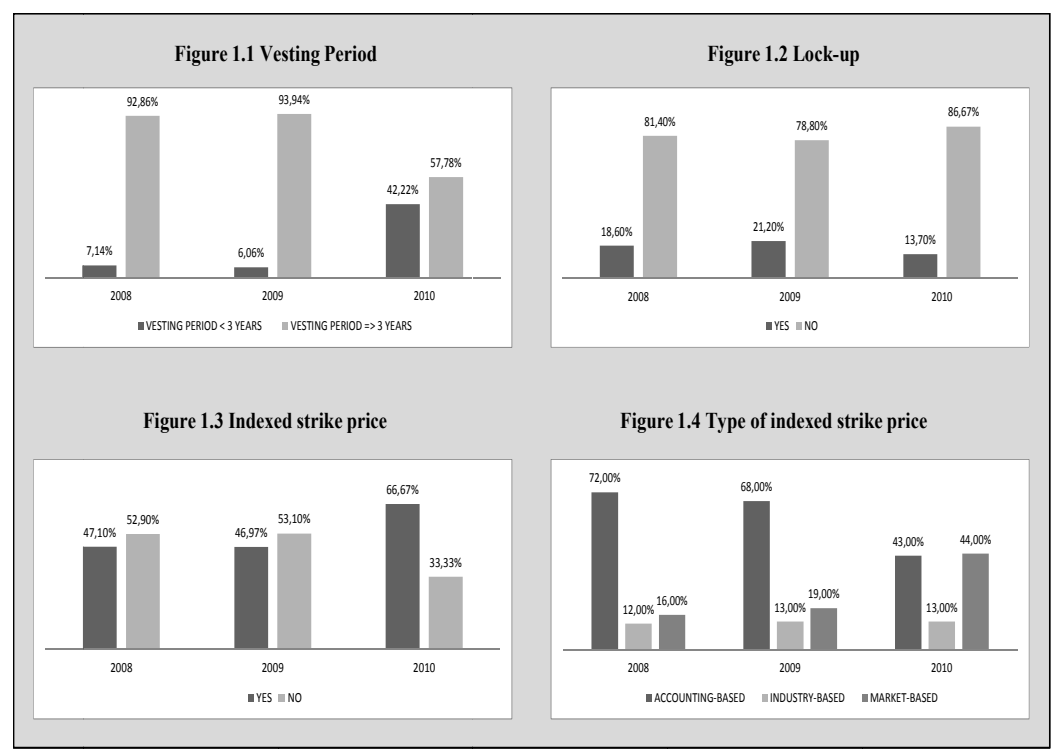

Figure 1. Distribution of SOPs characteristics

In 2008, about 93 per cent of companies adopt a vesting period under 3 years. This trend is similar in 2009 while in 2010, the percentage of companies that use a vesting period equal or longer than 3 years decreases. The evidence suggests that on average companies mainly use the equity incentive plans for purposes other than management retention. Similar arguments can be applied to the lock up period. During the observation window, most of the companies does not use lock-up conditions. This evidence reveals that sample firms tend to use SOPs to provide additional remuneration to executives and directors rather than retain and reward them. Finally, concerning the use of indexed strike price, the results show that in 2008 and 2009 , about $47 \%$ of the sample companies presents a strike price indexed to performance. In 2010, this percentage further decreases. More specifically, when we look at the type of indexed strike price, we find that SOPs are mostly linked to the accounting performance. Our findings suggest that companies do not employ SOPs for the original purpose of aligning the managerial interests towards the shareholder value maximization neither promote the managerial risk taking. What is more, companies that assign indexed SOPs seem to prefer accounting-based performance, which can be easily manipulated. This trend seems to reverse in more recent years, as reported by the increased percentage of market indexed strike price.

In order to obtain a comprehensive picture of the phenomenon under scrutiny, we construct an illustrative model showing the linkages between the SOPs characteristics and the compensation committee quality (Figure 2).

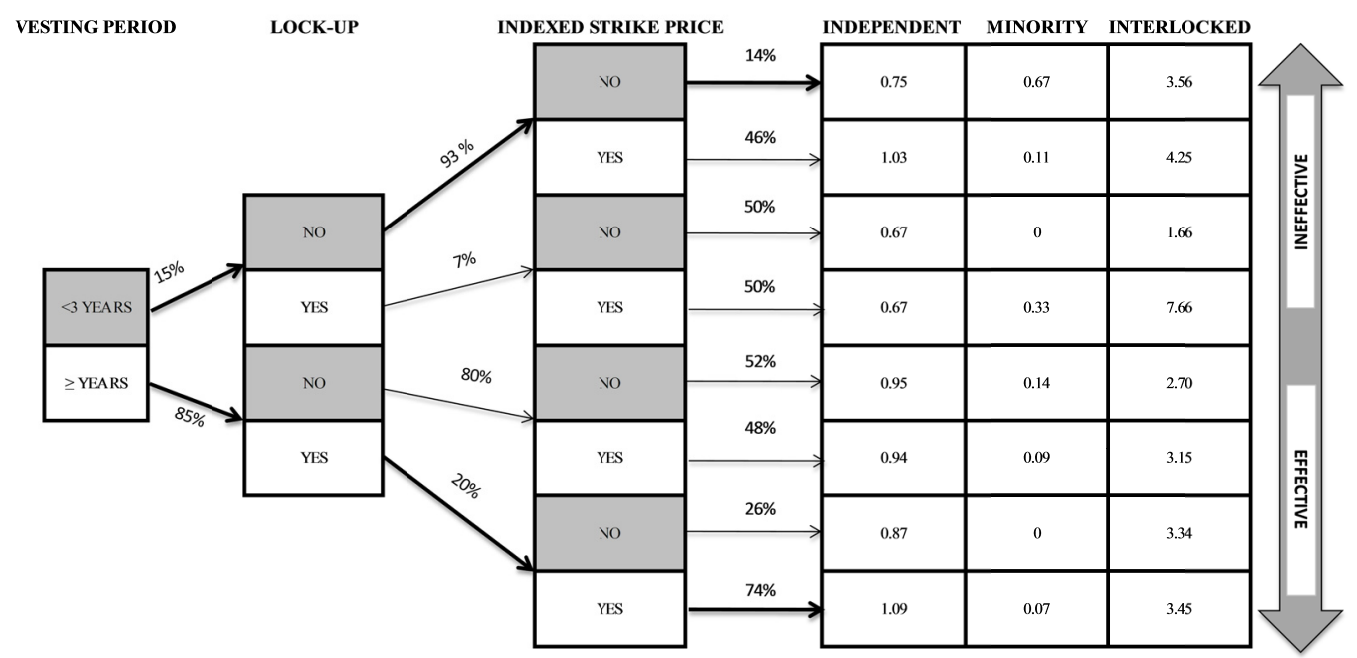

Figure 2. The relation between SOPs characteristics and compensation committee quality 
Specifically, the diagram reports the mean value of each compensation committee characteristics for each element of the effective SOPs design. In particular, the sample companies that seem to present an effective SOP in terms of vesting period equal or longer than 3 years, the presence of lock-up period, an indexed strike price exhibit a compensation committee with the following characteristics: (i) the mean value of independent directors equal to 1.09 , (ii) the mean value of minority directors equal to 0.07 , (iii) the mean value of interlocked directors equal to 3.45. Conversely, SOPs presenting an ineffective design seem to be granted by a compensation committee with a lower average value of independent directors and a higher average value of interlocked directors. Surprisingly, for plans belonging to this category we also observe a higher average value of directors appointed by minority shareholders. Table 1 shows the distribution of the variables under scrutiny for our sample.

Table 1. Descriptive statistics

\begin{tabular}{llllllll}
\hline Variable & $\min$ & $\max$ & mean & $\mathrm{sd}$ & $\mathrm{p} 25$ & $\mathrm{p} 50$ & $\mathrm{p} 75$ \\
\hline Panel $A$ & & & & & & & \\
\hline SO_VEP & 0 & 1 & 0.845 & 0.362 & 1 & 1 & 1 \\
SO_LOCKUP & 0 & 1 & 0.182 & 0.387 & 0 & 0 & 0 \\
SO_INDEX & 0 & 1 & 0.519 & 0.501 & 0 & 1 & 1 \\
\hline Panel B & & & & & & & \\
\hline IND_CC & 0 & 5 & 0.951 & 0.590 & 0.67 & 0.86 & 1 \\
INTERLOCK_CC & 0 & 14 & 3.161 & 2.580 & 1.25 & 2.333 & 4.666 \\
MIN_CC & 0 & 0.67 & 0.054 & 0.143 & 0 & 0 & 0 \\
LEV & 0.1 & 1.16 & 0.670 & 0.187 & 0.57 & 0.69 & 0.800 \\
SIZE & 0.693 & 12.196 & 6.43 & 3.279 & 3.279 & 7.406 & 8.777 \\
ROA & -0.302 & 0.261 & 0.037 & 0.067 & 0.006 & 0.043 & 0.072 \\
IPO & 3 & 146 & 23.839 & 27.523 & 8 & 12 & 25 \\
\hline
\end{tabular}

Panel A presents the descriptive statistics of the SOPs characteristics while Panel B reports the value for independent and control variables. We can observe that the statistics for the SOPs reflect the trend illustrated in Figure 1. As far as the compensation committee quality is concerned, the table reveals that the mean of IND_CC, INTERLOCK_CC, MIN_CR of our sample is 0.951 (median 0.86), 3.161 (median 2.333), 0.054 (median 0) respectively. These results suggest that in our sample firms the compensation committee is on average highly independent. Moreover, few directors are appointed by minority shareholders, while they are mostly interlocked with other subsidiary firms or corporation belonging to the same group. Finally, summary statistics of our control variables suggest that the sample firm is mostly leveraged, large and profitable.

\subsection{Correlation and Regression Analysis}

In order to deeply investigate the picture emerging from the diagram illustrated in Figure 2, we run a regression analysis. To this aim, we first construct a correlation matrix. Table 3 provides the matrix of Pearson correlation coefficients of the variables. We can observe that the characteristics of SOPs are all positively associated with each other. While the presence of interlocked directorship is negatively associated with the length of the vesting period, the presence of directors appointed by the minorities is positively associated with the indexed strike price. The correlation coefficients for control variables do not show any multicollinearity problem, suggesting that all the variables can be used in the empirical model at the same time (Guajarati, 2004). 
Table 3. Correlation matrix

\begin{tabular}{|c|c|c|c|c|c|c|c|c|c|c|}
\hline & 1 & 2 & 3 & 4 & 5 & 6 & 7 & 8 & 9 & 10 \\
\hline (1) SO_VEP & 1 & & & & & & & & & \\
\hline (2) SO_LOCKUP & $0.123 *$ & 1 & & & & & & & & \\
\hline (3) SO_INDEX & 0.047 & $0.196^{*}$ & 1 & & & & & & & \\
\hline (4) IND_CC & 0.061 & 0.052 & 0.063 & 1 & & & & & & \\
\hline (5) INTERLOCK_CC & $-0.129 *$ & 0.062 & 0.102 & 0.075 & 1 & & & & & \\
\hline (6) MIN_CC & -0.019 & 0.019 & $0.294^{*}$ & -0.022 & $-0.163^{*}$ & 1 & & & & \\
\hline (7) LEV & 0.007 & -0.025 & -0.077 & 0.119 & 0.018 & 0.010 & 1 & & & \\
\hline (8) SIZE & 0.423 & 0.098 & -0.054 & $0.196^{*}$ & -0.013 & -0.008 & $0.129 *$ & 1 & & \\
\hline (9) ROA & 0.003 & -0.029 & 0.284 & 0.059 & 0.023 & $0.180^{*}$ & $-0.296^{*}$ & 0.105 & 1 & \\
\hline (10) IPO & 0.007 & 0.070 & 0.019 & 0.007 & 0.041 & -0.077 & $0.163 *$ & $0.165^{*}$ & $-0.244 *$ & 1 \\
\hline
\end{tabular}

In order to test our hypotheses, we employ the following probit regression model:

$$
S O P=\beta_{0}+\beta_{1} I N D \_C C+\beta_{2} I N T E R L O C K_{-} C C+\beta_{3} M I N_{-} C C+\sum_{k}\left(\beta_{k} C O N T_{k}\right)+\varepsilon
$$

Where SOP, is alternatively SO_VEP, SO_LOCKUP or SO_INDEX; IND_CC, INTERLOCK_CC, MIN_CC are our main test variables; a vector of firm-specific variables represents control variables such as leverage, size, profitability and age. We also include industry and year fixed effects. The coefficients $\beta_{1}, \beta_{2}, \beta_{3}$ are the parameters to be estimated. Results of these estimations are reported in table 4.

Table 4. Regression analysis

\begin{tabular}{|c|c|c|c|}
\hline & $(1)$ & (2) & (3) \\
\hline Variables & SO_VEP & SO_LOCKUP & SO_INDEX \\
\hline \multirow[t]{2}{*}{ IND_CC } & -0.227 & 0.172 & 0.221 \\
\hline & $(0.304)$ & $(0.208)$ & $(0.232)$ \\
\hline \multirow[t]{2}{*}{ INTERLOCK_CC } & -0.0758 & 0.0404 & $0.0771 *$ \\
\hline & $(0.0479)$ & $(0.0455)$ & $(0.0442)$ \\
\hline \multirow[t]{2}{*}{ MIN_CC } & 0.548 & 0.459 & $3.870 * * *$ \\
\hline & $(0.875)$ & $(0.796)$ & $(1.159)$ \\
\hline \multirow[t]{2}{*}{ LEV } & -0.691 & -0.778 & -0.468 \\
\hline & $(0.683)$ & $(0.767)$ & $(0.592)$ \\
\hline \multirow[t]{2}{*}{ SIZE } & $0.222 * *$ & 0.0788 & -0.000616 \\
\hline & $(0.110)$ & $(0.0864)$ & $(0.0739)$ \\
\hline \multirow[t]{2}{*}{ ROA } & 0.699 & -0.901 & $6.987 * * *$ \\
\hline & $(1.939)$ & $(2.027)$ & $(2.285)$ \\
\hline \multirow[t]{2}{*}{ IPO } & $0.0178^{*}$ & 0.00185 & 0.00524 \\
\hline & $(0.0104)$ & $(0.00421)$ & $(0.00442)$ \\
\hline \multirow[t]{2}{*}{ Constant } & -0.0490 & $-1.524 * * *$ & -0.823 \\
\hline & $(0.710)$ & $(0.590)$ & $(0.564)$ \\
\hline YEAR FIXED EFFECT & YES & YES & YES \\
\hline INDUSTRY FIXED EFFECT & YES & YES & YES \\
\hline Observations & 181 & 181 & 181 \\
\hline
\end{tabular}

Column (1) reports the results for the regression using SO_VEP as dependent variable, while Column (2) and Column (3) show the results for the regression using SO_LOCKUP and SO_INDEX, respectively, as dependent variables. Regression coefficients for the models run in Column (1) and Column (2) for the variables of enquiry are almost in line with the expected signs, although they are not statistically significant. These results suggest that the quality of the compensation committee does not significantly affect the length of the vesting period, neither the provision of a lock-up period of SOPs.

Interestingly, when we run the regression model using SO_INDEX as dependent variable (Column 3) we find that the coefficient of INTERLOCK_CC is positive and slightly significant $\left(\beta_{2}=0.0771\right.$; $\mathrm{p}$-value $\left.<0.1\right)$. Moreover, we find MIN_CR is positive and statistically significant at $1 \%$ level $\left(\beta_{3}=3.870\right)$.

These results support our HP3 showing that the quality of compensation committee in terms of high presence of 
interlocked directors affects the settlement of an indexed strike price. In particular, the positive sign of the regression coefficient is in line with the prediction that the presence of directors that sit simultaneously in committee of several organizations signals their experience and reputation that is beneficial for the adoption of good practices of executive compensation. Consistent with our expectation, this evidence suggests that the higher the number of directors appointed by minorities, the higher the likelihood of having an indexed strike price.

Taken together, our results show that the compensation committee quality significantly influences the settlement of an indexed strike price that, among the other characteristics of well-designed SOPs, is the most relevant for the definition of incentive compensation contracts.

\section{Conclusion}

This study investigates the influence of compensation committee quality on the effective design of SOPs for the alignment of managerial goals with those of shareholders. Specifically, we examine whether compensation committee quality affects the length of the vesting period, the settlement of a lock up period, and the provision of an indexed strike price.

Differently from prior research that focuses on compensation committee independence, we identify the presence of interlocked directors and of the directors appointed by minorities as additional characteristics in order to comprehensively capture the quality of compensation committee.

Using a sample of Italian listed companies issuing SOPs, all with a compensation committee, we run an empirical analysis based on two steps. First, we perform a descriptive analysis on the SOPs issued by our sample firms, in order to show the evolution of the plan characteristics over the observation period. We also construct an illustrative model that shows the linkages between the compensation committee characteristics and each element of the effective SOPs design. Second, we run a probit regression analysis in order to test the statistical association between the above mentioned variables.

Our results document that the quality of compensation committee significantly affects the assignment of effective SOPs. In particular, we find that the presence of interlocked directors and of directors appointed by minorities affects the settlement of an indexed strike price. This finding is particularly significant since, among the other investigated characteristics, the presence of an indexed strike price is the most important element of SOPs designed for incentive purposes.

Our study offers theoretical and practical implications. First, by exploring the composition of the compensation committee and its influence on the design of SOPs we contribute to the existing governance literature on the effectiveness of executive remuneration in the alignment of interests between managers and shareholders. Second, we differentiate from other studies which focused on the independence itself, and observe that there are other compensation committee characteristics that matter for the effectiveness of SOPs, i.e. the presence of experienced directors with multiple appointments and of directors representative of minorities. This evidence broadens the current knowledge on the compensation committee, by showing that the investigation of independence as unique structural characteristic is not sufficient to capture whether SOPs are tailored to pursue shareholder value creation. Third, we contribute to the research on SOPs by highlighting that the presence of an indexed strike price is a key element of incentive executive remuneration contracts.

From the perspective of practitioners our study offers several contributions. Specifically, it provides investors with information useful to assess the quality of compensation committee in the pursuing of shareholder value maximization. Furthermore, our findings suggest that the policymakers should devote specific attention to the overall quality of compensation committees by requiring the presence of highly reputed members and directors representative of minorities in the best practice codes.

Finally, we recognize that our study has certain limitations. First, other compensation committee characteristics, in addition to those investigated in the current study might also affect compensation committee quality. Similarly, other elements of SOPs, such as the assignment of at/out of the money option and the re-pricing practice, might be investigated as additional proxies of well written executive remuneration contracts. Second, our study is limited to a single country, even if the results can be extended to other closely held firm settings. In this sense, future research may examine the effect of compensation committee quality on executive remunerations also in countries with different characteristics in order to corroborate the reported evidence. 


\section{References}

Abernethy, M., Kuang, Y., \& Qin, B. (2015). The Influence of CEO Power on Compensation Contract Design. The Accounting Review, 90(4), 1265-1306. http://dx.doi.org/10.2308/accr-50971

Anderson, R. C., \& Bizjak, J. M. (2003). An empirical examination of the role of the CEO and the compensation committee in structuring executive pay. Journal of Banking \& Finance, 27(7), 1323-1348. http://dx.doi.org/10.1016/S0378-4266(02)00259-5

Arena, C., Catuogno, S., Cirillo, A., \& Pennacchio, L. (2016). Extract or not extract? The effect of familism on stock option plans. International Journal of Business and Management, 11(5). http://dx.doi.org/10.5539/ijbm.v11n5p82

Barca, F., \& Becht, M. (2001). The control of corporate Europe. Oxford University Press. http://dx.doi.org/10.1093/0199257531.001.0001

Barkema, H. G., \& Gomez-Mejia, L. R. (1998). Managerial compensation and firm performance: A general research framework. Academy of Management Journal, 41(2), 135-145. http://dx.doi.org/10.2307/257098

Barontini, R., \& Bozzi, S. (2011). Board compensation and ownership structure: empirical evidence for Italian listed companies. Journal of Management \& Governance, 15(1), 59-89. http://dx.doi.org/10.1007/s10997-009-9118-5

Bebchuk, L. A., Fried, J., \& Walker, D. (2002). Managerial power and rent extraction in the design of executive compensation. University of Chicago Law Review, 69, 751-846. http://dx.doi.org/10.2307/1600632

Bebchuk, L., \& Fried, J. (2003). Executive compensation as an agency problem. Journal of Economic Perspectives, 17(3), 71-92. http://dx.doi.org/10.3386/w9813

Bertrand, M., \& Mullainathan, S. (2001). Are CEOs rewarded for luck? The ones without principals are. Quarterly Journal of Economics, 901-932. http://dx.doi.org/10.1162/00335530152466269

Carpenter, M. A., \& Westphal, J. D. (2001). The strategic context of external network ties: Examining the impact of director appointments on board involvement in strategic decision making. Academy of Management Journal, 44(4), 639-660. http://dx.doi.org/10.2307/3069408

Catuogno, S., Saggese, S., Sarto, F., \& Viganò, R. (2015). Shedding light on the aim of stock options: A literature review. Journal of Management \& Governance, 1-25. http://dx.doi.org/10.1007/s10997-015-9318-0

Chhaochharia, V., \& Grinstein, Y. (2009). CEO compensation and board structure. The Journal of Finance, 64(1), 231-261. http://dx.doi.org/10.1111/j.1540-6261.2008.01433.x

Claessens, S., Djankov, S., \& Lang, L. H. (2000). The separation of ownership and control in East Asian $\begin{array}{lllll}\text { corporations. Journal of } & \text { Financial }\end{array}$ http://dx.doi.org/10.1016/S0304-405X(00)00067-2

Conyon, M. J., \& He, L. (2004). Compensation committees and CEO compensation incentives in US entrepreneurial firms. Journal of Management Accounting Research, 16(1), 35-56. http://dx.doi.org/10.2139/ssrn.546110

Conyon, M. J., \& Peck, S. I. (1998). Board control, remuneration committees, and top management compensation. Academy of Management Journal, 41(2), 146-157. http://dx.doi.org/10.2307/257099

Conyon, M. J. (2014). Executive compensation and board governance in US firms. Economic Journal, 124(574), 60-89. http://dx.doi.org/10.1111/ecoj.12120

Core, J. E., Guay, W. R., \& Larcker, D. F. (2003). Executive equity compensation and incentives: A survey. Economic policy review, 9(1). http://papers.ssrn.com/abstract $=276425$

Cotter, J. F., Shivdasani, A., \& Zenner, M. (1997). Do independent directors enhance target shareholder wealth during tender offers? Journal of Financial Economics, 43(2), 195-218. http://dx.doi.org/10.1016/S0304-405X(96)00886-0

Daily, C. M., Johnson, J. L., Ellstrand, A. E., \& Dalton, D. R. (1998). Compensation committee composition as a determinant of CEO compensation. Academy of Management Journal, 41(2), 209-220. http://dx.doi.org/10.2307/257103

Faccio, M., \& Lang, L. H. (2002). The ultimate ownership of Western European corporations. Journal of Financial Economics, 65(3), 365-395. http://dx.doi.org/10.1016/S0304-405X(02)00146-0 
Fama, E. F. (1980). Agency problems and the theory of the firm. The Journal of Political Economy, 288-307. http://dx.doi.org/10.1086/260866

Fama, E. F., \& Jensen, M. (1983a). Separation of ownership and control. Journal of Low, Economics \& Organization, 26, 301-325. http://dx.doi.org/10.1086/467037

Fama, E. F., \& Jensen, M. (1983b). Agency problems and residual claims. Journal of Low, Economics \& Organization, 26, 327-349. http://dx.doi.org/10.1086/467038

Fich, E. M., \& Shivdasani, A. (2006). Are busy boards effective monitors? The Journal of Finance, 61(2), 689-724. http://dx.doi.org/10.1111/j.1540-6261.2006.00852.x

Fudenberg, D., Holmstrom, B., \& Milgrom, P. (1990). Short-term contracts and long-term agency relationships. Journal of Economic Theory, 51(1), 1-31. http://dx.doi.org/10.1016/0022-0531(90)90048-O

Gong, J. J. (2011). Examining Shareholder Value Creation over CEO Tenure: A New Approach to Testing Effectiveness of Executive Compensation. Journal of Management Accounting Research, 23(1), 1-28. http://dx.doi.org/10.1111/ecoj.12120

Gujarati, D. N. (2004). Econométrie. De Boeck Superieur. Retrieved from https://books.google.it/books?hl=it\&lr=\&id=DwJttLDlIn4C\&oi=fnd\&pg=PA1\&ots=XDMU9DSAAo\&sig $=8 \mathrm{Mjj} 2 \mathrm{DxVE} 2 \mathrm{cUXUR} 1 \mathrm{x} 8 \mathrm{~V} 3 \mathrm{CpJKOzc \# v}$

Hall, B. J., \& Liebman, J. B. (2000). The taxation of executive compensation. Tax Policy and the Economy, 14, 1-44. http://dx.doi.org/10.1086/654701

Healy, P. M., \& Palepu, K. G. (2003). How the quest for efficiency undermined the market. Harvard Business Review, 81(7), 76-85. http://ssrn.com/abstract=422524

Hillman, A. J., Keim, G. D., \& Luce, R. A. (2001). Board composition and stakeholder performance: Do stakeholder directors make a difference? Business \& Society, 40(3), 295-314. http://dx.doi.org/10.1177/000765030104000304

Jensen, M. C., \& Murphy, K. J. (1990). Performance pay and top-management incentives. Journal of Political Economy, 225-264. http://dx.doi.org/10.1086/261677

Jensen, M., \& Meckling, W. (1976). The theory of the firm. Managerial behaviour, agency costs and ownership $\begin{array}{llll}\text { structure. Journal of Financial } & \text { Economics, } & 3(4), & \text { 305-360. }\end{array}$ http://dx.doi.org/10.1016/0304-405X(76)90026-X

Jensen, M., \& Zajac, E. J. (2004). Corporate elites and corporate strategy: How demographic preferences and structural position shape the scope of the firm. Strategic Management Journal, 25(6), 507-524. http://dx.doi.org/10.1002/smj.393

Johnson, S. A., \& Tian, Y. S. (2000). The value and incentive effects of nontraditional executive stock option plans. Journal of Financial Economics, 57(1), 3-34. http://dx.doi.org/10.1016/S0304-405X(00)00049-0

Johnson, S., La Porta, R., Lopez-de-Silanes, F., \& Shleifer, A. (2000). Tunneling. American Economic Review, 90(2), 22-27. http://dx.doi.org/10.1257/aer.90.2.22

Klein, A. (2003). Likely effects of stock exchange governance proposals and Sarbanes-Oxley on corporate boards and financial reporting. Accounting Horizons, 17(4), 343-355. http://dx.doi.org/10.2308/acch.2003.17.4.343

Kuang, Y. F., \& Quin, B. (2009). Performance-vested stock option and interest alignment. The British Accounting Review, 41, 46-61. http://dx.doi.org/10.1016/j.bar.2008.10.001

La Porta, R., Lopez-de-Silanes, F., Shleifer, A., \& Vishny, R. (1999). The quality of government. Journal of Law, Economics, and organization, 15(1), 222-279. http://dx.doi.org/10.1093/jleo/15.1.222

Li, D., Moshirian, F., Nguyen, P., \& Tan, L. (2007). Corporate governance or globalization: What determines CEO compensation in China? Research in International Business and Finance, 21(1), 32-49. http://dx.doi.org/10.1016/j.ribaf.2005.12.003

Liljeblom, E., Pasternack, D., \& Rosenberg, M. (2011). What Determines Stock Option Contract Design? Journal of Financial Economics, 102(2), 293-316. http://dx.doi.org/10.1111/ecoj.12120

Liu, L., Liu, H., \& Yin, J. (2014). Stock Option Schedules and Managerial Opportunism. Journal of Business Finance and Accounting, 41(5-6), 652-684. http://dx.doi.org/10.1111/jbfa.12075 
Melis, A. (2000). Corporate Governance in Italy. Corporate Governance: An International Review, 8(4), 347-55. http://dx.doi.org/10.1111/1467-8683.00213

Melis, A., Carta, S., \& Gaia, S. (2012). Executive remuneration in blockholder-dominated firms. How do Italian firms use stock options? Journal of Management \& Governance, 16(3), 511-541. http://dx.doi.org/10.1007/s10997-010-9163-0

Newman, H. A., \& Mozes H. A. (1999). Does composition of the compensation committee influence CEO compensation practice? Financial Management, 28(3), 41-53. http://dx.doi.org/10.2307/3666182

Peng, L., \& Röell, A. (2008). Executive pay and shareholder litigation. Review of Finance, 12(1), 141-184. http://dx.doi.org/10.1093/rof/rfl003

Pfeffer, J. (1991). Organization theory and structural perspectives on management. Journal of Management, 17(4), 789-803. http://dx.doi.org/10.1177/014920639101700411

Qin, B. (2012). The influence of firm and executive characteristics on performance-vested stock option grants. International Business Review, 21(5) 906-928. http://dx.doi.org/10.1016/j.ibusrev.2011.10.004

Shivdasani, A. (1993). Board composition, ownership structure, and hostile takeovers. Journal of Accounting and Economics, 16(1), 167-198. http://dx.doi.org/10.1016/0165-4101(93)90009-5

Sun, J., \& Cahan, S. (2009). The effect of compensation committee quality on the association between CEO cash compensation and accounting performance. Corporate Governance: An International Review, 17(2), 193-207. http://dx.doi.org/10.1111/j.1467-8683.2008.00726.x

Sun, J., Cahan, S. F., \& Emanuel, D. (2009). Compensation committee governance quality, chief executive officer stock option grants, and future firm performance. Journal of Banking \& Finance, 33(8), 1507-1519. http://dx.doi.org/10.1016/j.jbankfin.2009.02.015

Vafeas, N. (2003). Further evidence on compensation committee composition as a determinant of CEO compensation. Financial Management, 2, 53-70. http://dx.doi.org/10.2307/3666336

Viscogliosi, B., \& Zattoni, A. (2008). La diffusione dei piani di stock option in Italia-situazione attuale e prospettive future. Economia \& Management, 1, 69-89. http://hdl.handle.net/11385/147634

Williamson, O. E. (1979). The governance of contractual relations. Journal of Law and Economics, 22(2), 233-261. http://dx.doi.org/10.1017/CBO9780511817410.011

Yermack, D. (1995). Do corporations award CEO stock options effectively? Journal of Financial Economics, 39(2), 237-269. http://dx.doi.org/10.1016/0304-405X(95)00829-4

Zattoni, A., \& Minichilli, A. (2009). The diffusion of equity incentive plans in Italian listed companies: what is the trigger? Corporate Governance: An International Review, 17(2), 224-237. http://dx.doi.org/10.1111/j.1467-8683.2009.00732.x

Zattoni, A., (2007). Stock incentive plans in Europe: Empirical evidence and design implications. Corporate Ownership and Control, 4(4), 55-64. Retrieved from http://www.virtusinterpress.org/IMG/pdf/COC_Volume_4_Issue_4_Summer_2007_.pdf\#page=68

Zona, F. (2016). Agency models in different stages of CEO tenure: The effects of stock options and board independence on R\&D investment. Research Policy, Elsevier B. V., 45(2), 560-575. http://dx.doi.org/10.1016/j.respol.2015.10.012

\section{Copyrights}

Copyright for this article is retained by the author(s), with first publication rights granted to the journal.

This is an open-access article distributed under the terms and conditions of the Creative Commons Attribution license (http://creativecommons.org/licenses/by/3.0/). 